Napis XV 2009

„Wiersze polityczne czasu konfederacji targowickiej

i sejmu grodzieńskiego 1793 roku", opracowała Krystyna Maksimowicz, Gdańsk 2008, Wydawnictwo Uniwersytetu Gdańskiego, ss.478.

s. $380-383$

Wojciech Kaliszewski 
w epoce, bądź też nadano je dla potrzeb obecnej edycji. Gdyby policzyć osobno utwory wchodzące w skład cyklów w poszczególnych tomach, podana wyżej liczba jeszcze by wzrosła, ale niezależnie od tego, jaki przyjmiemy sposób liczenia, mamy do czynienia $z$ ogromnym zbiorem.

Podsumowując, edycja imponuje rozleghością zebranego materialu literackiego, po raz pierwszy udostępnionego czytelnikom na taką skalę. Przynosi wiele utworów dotychczas nieznanych. Jest adresowana do środowiska naukowego, ale z powodzeniem może sięgnąć po tę lekturę odbiorca zainteresowany podjętą w niej problematyką. Dzięki tej publikacji na czasy konfederacji barskiej można spojrzeć szeroko z punktu widzenia literaturoznawcy, który twórczość barską postrzega jako jeden z etapów rozwoju okolicznościowej literatury politycznej w Polsce. Wydane teksty stanowią prawdziwą kopalnię bardziej lub mniej głębokiej, ale niezwykle cennej wiedzy na temat naszej przeszłości. Cała edycja jest wielkim osiągnięciem badawczym Janusza Maciejewskiego i Jego Zespołu.

Krystyna Maksimowicz

\begin{abstract}
Wiersze polityczne czasu konfederacji targowickiej i sejmu grodzieńskiego 1793 roku, opracowała Krystyna Maksimowicz, Gdańsk 2008, Wydawnictwo Uniwersytetu Gdańskiego 2008, ss. 478.
\end{abstract}

Tom Wiersze polityczne czasu konfederacji targowickiej i sejmu grodzieńskiego 1793 roku opracowany przez Krystynę Maksimowicz wypetnia istniejącą dotąd lukę w prezentacji poezji politycznej czasów panowania Stanislawa Augusta. Pod rządami tego monarchy Rzeczpospolita przeżywała prawdziwie groźne i dramatyczne chwile. Warto przypomnieć, że polityczne spory przeciwników i zwolenników Poniatowskiego, tak wyraźnie zaznaczone już w czasie bezkrólewia, po śmierci Augusta III Sasa w 1763 roku nie wygasły i tlily się przez cale trzydziestolecie rządów ostatniego władcy Polski, wybuchając co pewien czas ogniem wewnętrznych konfliktów. Istota owych sporów tkwila w odmiennym pojmowaniu wolności, nie tylko jako prawa gwarantującego podmiotowy byt jednostki, ale także jako fundamentu politycznego istnienia państwa. Historia tego sporu zamknięta klamrami dat rocznych 1763 i 1793 jest — niestety — także historią kurczącego się dramatycznie obszaru polskiej suwerenności i niezależności decyzyjnej. Sterowane przez rządy coraz bardziej potężnych sąsiadów polskie fakcje polityczne stawaly się zakladnikami europejskich monarchii, kreślących nową mapę podziału kontynentu.

Omawiany tom przynosi 145 utworów, stanowiących aktualny wierszowany komentarz do wydarzeń lat 1792-1793. Sytuacja polityczna tego okresu była niezwykle napięta 
— z jednej strony obradujący od 1788 roku sejm stwarzał podstawy do istotnej i nowocześnie zaprojektowanej przebudowy struktur państwa, z drugiej zaś gwaltownie radykalizowało się stanowisko obrońców status quo. Szczęsny Potocki i Seweryn Rzewuski manifestacyjnie opuścili Polskę, by wkrótce ogłosić się jedynymi obrońcami prawdziwej wolności Rzeczypospolitej. Zawiązana przez nich konfederacja targowicka miała być odpowiedzią na uchwaloną 3 maja 1791 roku Konstytucję, a także na wszystkie inne ustawy Sejmu Wielkiego. W grę nie wchodził więc dialog stron, a kompromis był z góry wykluczony. Malkontenci — jak Potockiego i Rzewuskiego nazywa Juliusz Nowak-Dlużewski — zwrócili się wprost do Rosji, stwarzając Katarzynie II doskonaty pretekst do ingerencji i działań na terenie Polski. W kraju wrzało i dla nikogo nie było tajemnicą, że stanie się to, co zapowiadal niezwykle wtedy aktywny obrońca ustaw sejmowych, Niemcewicz:

Niechaj zatrą wzajemne ognie i pałasze:

Pokażmy światu, w polu stawiając się godnie,

Kto cnoty, a kto srogie prześladuje zbrodnie ${ }^{1}$.

Edycja Wierszy politycznych czasu konfederacji targowickiej... pozwala spojrzeć na teatr tamtych dramatycznych wydarzeń w sposób prawie kompletny i ramowo uporządkowany. Jest to perspektywa ważna, nie da się jej zastąpić ani lekturą pism politycznych, ani tym bardziej komentarzem historycznym. Okolicznościowa poezja polityczna ma zawsze przewagę nad wszystkimi innymi zapisami źródłowymi, bowiem polega ona na uchwyceniu i zachowaniu w stanie zbliżonym do autentycznych przeżyć zrodzonych bezpośrednio w ogniu wydarzeń. Czytelnik zyskuje więc — dzięki takiej edycji - niepowtarzalną szansę, by poczuć się swoistym adresatem pobudek, apeli i wezwań, ale także głębiej zrozumieć gniew i oburzenie wywoływane przez nazwiska zdrajców.

W świetle zebranych w tomie wierszy wypadki lat 1792-1793 charakteryzują się ciekawą dynamiką, która - jak wyraźnie wynika z lektury - miała swe źródlo również w sytuacji zagranicznej. Wydarzenia Wielkiej Rewolucji Francuskiej stawały się w sposób oczywisty kontekstem dla sytuacji społeczno-politycznej w Polsce. O szukaniu i dostrzeganiu wówczas takich analogii świadczą wymownie choćby liczne przeróbki i nawiązania do francuskiej pieśni Ça ira.

Wiersze polityczne czasu konfederacji targowickiej... mają charakter edycji źródlowej. To pierwsza taka edycja tych materiałów, chociaż warto pamiętać, że wiele z zamieszczonych tutaj wierszy znalazło się wcześniej w antologiach poezji oświeceniowej. Wydanie o charakterze źródłowym nakłada na edytora szereg obowiązków i zmusza

1 J. U. Niemcewicz, Do rycerstwa polskiego przy wyjeździe J. K. Mci do obozu. Dnia czerwca roku 1792, w: Wiersze polityczne czasu konfederacji targowickiej i sejnu grodzieńskiego 1793 roku, oprac. K. Maksimowicz, Gdańsk 2008, s. 97-98. 
go do rozstrzygania licznych kwestii związanych z poprawnością tekstu i jego atrybucją. W przypadku okolicznościowej poezji politycznej nie jest to łatwe. Bardzo często - co zrozumiale - autorzy nie chcieli ujawniać swoich nazwisk, a nawet celowo wprowadzali fałszywe tropy, mające zmylić tych, którzy podjęliby się próby ich odszukania. Ostatecznie udało się ustalić tylko dwunastu autorów. Są wśród nich: Julian Niemcewicz — pisarz bardzo aktywny w czasie obrad Sejmu Czteroletniego — Wojciech Bogusławski, Józef Wybicki i Stanisław Trembecki. Działania atrybucyjne zostały szczególowo przedstawione we wstępie do edycji. Warto jednak zauważyć, że ta lista nie może być uznana za zamkniętą. Istnieje bowiem prawdopodobieństwo, że uda się ją, być może, poszerzyć w trakcie kolejnych kwerend i poszukiwań.

Wydanie wierszy politycznych z czasów konfederacji targowickiej i sejmu grodzieńskiego pozwala poznać stosunek znacznej części opinii szlacheckiej nie tylko do dramatycznych wydarzeń tego okresu, ale także do samych przywódców konfederacji. Ich wierszowane portrety, kreślone najczęściej przez obrońców ustaw Sejmu Czteroletniego, tworzą galerię ludzi złych, pozbawionych godności i milości do ojczyzny. Ton potępienia konfederacji targowickiej w wielu utworach wprost prowadzi do nazwania jej twórców zdrajcami. Przeciwko ich działaniom kierowane są apele, wezwania i pobudki do stawania w obronie wolności i honoru. Oto jak wołał jeden z anonimowych autorów tego czasu:

Narodzie, pomnij sławy, jakiejeś dochodził!

Czy się jarzmem niewoli brzydziłeś pozornie?

Czyż się na to w swej sławie i prawach odrodzit,

Abyś podłe kajdany brał na się pokornie?2

Apel do zachowania zbiorowej pamięci o dawnych cnotach jest wymownym dowodem budowania jasno określonej tożsamości i solidarności politycznej opartej na prawie do samostanowienia. Jednocześnie autor wskazuje na nowy wzorzec politycznego projektu ratowania Polski, jakim byly ustawy sejmu z lat 1788-1792. Zarysowana tutaj alternatywa niewoli i wolności jest teraz i byla wówczas czytelnym układem przeciwieństw, mających istotny wpływ na niepodległy byt narodu.

Dzięki tym wierszom możemy prześledzić wzrost napięcia politycznego i temperatury emocji, która rzeczywiście osiągała wówczas najwyższe wartości. I taka wlaśnie rola edycji jest nie do przecenienia nie tylko dla historyka literatury, ale także dla historyka dziejów politycznych Pierwszej Rzeczypospolitej.

Autorka opracowania poprzedziła edycję wstępem, który stanowi po pierwsze ważny komentarz wydawniczy, po drugie kreśli to historyczne i porządkuje genezę wypadków bezpośrednio wywołujących wierszowane reakcje polityczne. Złożone kwestie

2 N.N., Do narodu, w: Wiersze polityczne..., op. cit., s. 251. 
polityczne i personalne tego okresu uzyskały we wprowadzeniu Krystyny Maksimowicz syntetyczny i przejrzysty obraz. Wstęp ukazuje także całą skalę problematyki targowickiej i grodzieńskiej, skłaniając dzisiejszego odbiorcę do bardziej wyważonych ocen postaw i podejmowanych wówczas indywidualnych decyzji.

Lektura komentarza edytorskiego pozwala natomiast zorientować się w trudnościach, wspomnianej już wyżej, kwestii atrybucji i sposobach ustalania podstaw wydania. Wraz z umieszczonymi przy każdym wierszu przypisami stanowi on opis działań edytorskich. W tym obszarze mieści się także swoista historia edycji, której nie można pominąć i w której nie mogło zabraknąć nazwisk tak znakomitych i wytrwałych badaczy poezji politycznej jak Juliusz Nowak-Dłużewski, Edmund Rabowicz czy Roman Kaleta. To także dzięki ich wcześniejszym kwerendom wydanie to mogło się ostatecznie ukazać.

Wiersze polityczne czasu konfederacji targowickiej i sejmu grodzieńskiego 1793 roku zbierają i prezentują utwory zgodnie ze stanem dzisiejszej wiedzy i wynikami dotychczasowych poszukiwań. Uzupełnienie w ten sposób luki w historii poezji politycznej XVIII wieku zasługuje nie tylko na uwagę, ale i na pochwałę.

Wojciech Kaliszewski

\section{Alina Kowalczykowa, Świadectwo autoportretu, Warszawa 2008, wydawcy: Biblioteka WWSH, Fundacja Humanistyczna, IBL PAN, ss. 187 (187 ilustracji + indeks nazwisk)}

Książka o dziejach malarstwa, której autorem nie jest historyk sztuki, często budzi niepokój i podejrzenie, czy nie jest to kolejny zbiór pięknie napisanych esejów, choćby tak wspaniałych jak klasyczne dzieło Zbigniewa Herberta ${ }^{1}$; on sam przecież czuł się wśród dzieł sztuki jak „barbarzyńca”. Książka napisana przez badacza literatury może rodzić pytania o związki i możliwość relacji między światem sztuki i dzielami literackimi.

W dziejach kultury ważna rolę odegrał, nieco przypadkowo, słynny postulat Horacego, aby dzieło literackie analizować jak obraz. Sam Horacy, nawiązał owym: Ut pictura poesis do aforyzmu Simonidesa z Kos (Vw. p.n.e.): „Poezja jest mówiącym malarstwem, obraz niemym poematem".

Literaturoznawcy zawsze pragnęli, żeby obraz był jak literatura: aby można o nim pisać tak, jak o dziele pisarza. Stąd zapewne wzięła się pokusa, aby historię sztuki

1 Zob. jedną z pozycji Herbertowskiego cyklu esejów o sztuce Barbarzyńca w ogrodzie (Warszawa 1962). 